УДК: $346.543 ; 339.727 .22$

CERIF: S 144, S 146

ТИП РАДА: ПРЕГЛЕДНИ НАУЧНИ РАД

DOI: $10.5937 / \mathrm{PiP} 2101035 \mathrm{M}$

Катиарина МАЛЕТИЋ, мастер

судијски сарадник Вишег суда у Београду, Република Србија

\author{
МЕБУНАРОДНО ИНВЕСТИЦИОНО ПРАВО \\ И ЗАШТИТА РАДНИХ ПРАВА: СТАНДАРД \\ ПОШТЕНОГ И ПРАВИЧНОГ ТРЕТМАНА \\ И ИНДИРЕКТНА ЕКСПРОПРИЈАЦИЈА \\ У СВЕТЛУ ИЗМЕНА РАДНОПРАВНИХ \\ ПРОПИСА ДРЖАВЕ ДОМАТИНА
}

\begin{abstract}
Сажетак
Циљ овоі̄ раgа је gа оgїовори на йитиане gа ли улаїачи моїу осӣори-

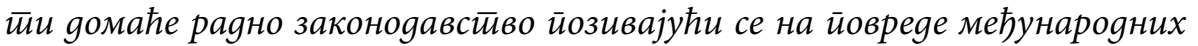

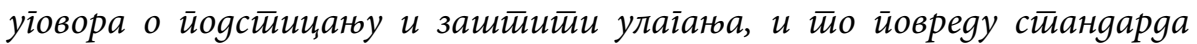

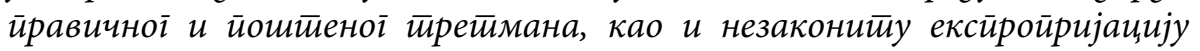

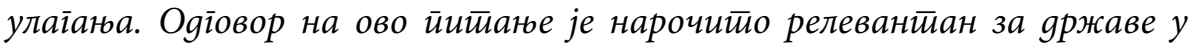
развоју, йойуй Рейублике Србије, које насииоје gа усклаgе свој йравни йо-

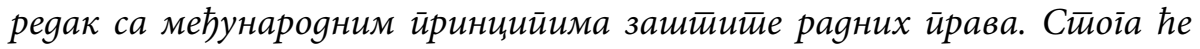

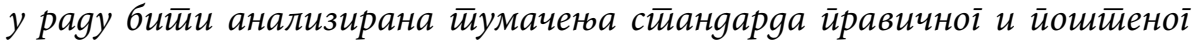

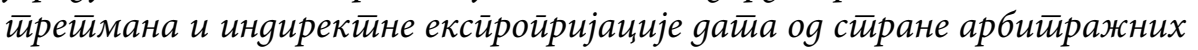
иррибунала и ирихваћена у научној литератиури, као и нихова ирримена у светилу измена раgноиравних ирройиса. Значајна йажна је йосвећена и
\end{abstract}

* Електронска адреса аутора: maletic.katarina1@gmail.com. 


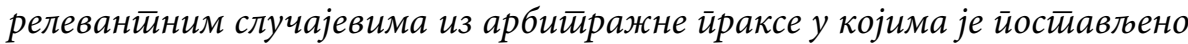

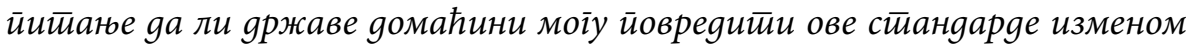
својих йройиса о раgу. Исйраживане је йоказало gа измене gомаће ре-

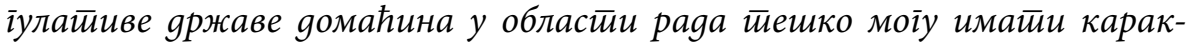

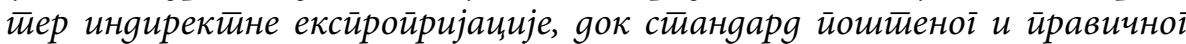

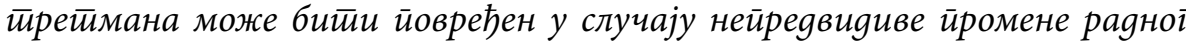

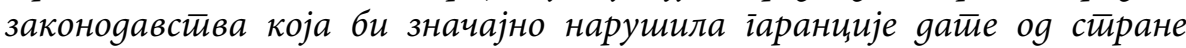

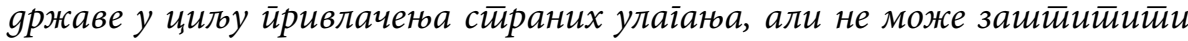
улаїаче og увођень bопа fide раgнойравних йройиса.

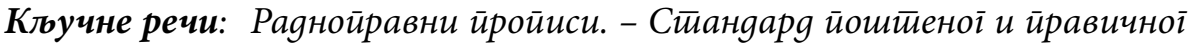

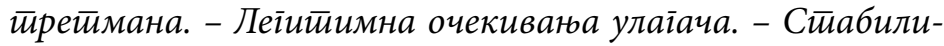
заиионе клаузуле. - Индирекйна ексӣройријација.

\section{І Увод}

Међународно инвестиционо право се често тумачи као „једнострано“, пружајући већи ниво заштите улагачевим интересима у односу на интересе државе домаћина. ${ }^{1}$ Неки аутори су мишљења да је проширивање обима и јачање права страних инвеститора довело до неједнаког односа између улагача и држава домаћина, што је последично имало утицаја и на сферу заштите људских права. ${ }^{2}$ Наиме, међународни уговори о унапређењу и заштити улагања омогућавају инвеститорима да покрену поступак против државе домаћина пред међународном арбитражом. У овим поступцима улагачи потражују накнаду за штету која је за њих настала доношењем и применом законодавства државе домаћина усмереног ка подстицању и подизању нивоа заштите друштвених и еколошких стандарда. ${ }^{3}$

Описана тенденција привилеговања улагача у инвестиционом праву може имати неповољне последице на обезбеђивање заштите права радника и успостављање одговарајућих услова рада у мање развијеним земљама. Наиме, земље у развоју, попут Републике Србије, настоје да

1 За дискусију на ову тему вид. Charles Brower, Sadie Blanchard, „What's in a Meme? The Truth about Investor-State Arbitration: Why It Need Not, and Must Not, be Repossessed by States", Columbia Journal of Transnational Law, Vol. 52, Nr. 3/2014, 709-716.

2 Barnali Choudhury, „Investor Obligations for Human Rights“, ICSID Review (Forthcoming), 2019, доступно на адреси: https://ssrn.com/abstract=3500991, 10. 1. 2021, 4.

3 UN Human Rights Council, „Protect, Respect and Remedy: A Framework for Business and Human Rights - Report of the Special Representative of the Secretary-General on the Issue of Human Rights and Transnational Corporations and Other Business Enterprises“, U.N. Doc. A/HRC/8/5, 2008, доступно на адреси: https://undocs.org/en/A/ $H R C / 8 / 5,10.1 .2021$, пара. 12. 
ускладе свој правни поредак са међународним принципима заштите радних права, као што су они које Међународна организација рада промовише у својим конвенцијама и препорукама. ${ }^{4}$ Стога, може се десити да државе изменом домаћег радног законодавства настоје да успоставе и примењују више стандарде у погледу услова рада, а све како би поступиле у складу са неком од ратификованих конвенција Међународне организације рада. Истовремено, доношење и примена ових правила би могла повећати трошкове улагања и тиме негативно утицати на улагачеве интересе. Другим речима, користећи своје право да регулишу питања од јавног интереса, државе уједно могу штетно утицати на интересе страних инвеститора и тиме ризиковати покретање арбитражног поступка.

Циљ овог рада је да одговори на питање да ли улагачи могу оспорити домаће радноправно законодавство позивајући се на повреде међународних уговора о подстицању и заштити улагања, и то повреду стандарда правичног и поштеног третмана, као и незакониту експропријацију улагања. Стога ће бити анализирана тумачења ових стандарда дата од стране арбитражних трибунала и прихваћена у научној литератури, као и њихов однос са заштитом радних права, односно њихова примена у светлу измена радноправних прописа. Такође, биће речи и о релевантним случајевима из арбитражне праксе у којима се поставило питање да ли се измене прописа о раду држава домаћина могу сматрати незаконитом експропријацијом улагања или повредом улагачевих легитимних очекивања.

\section{II Стандард поштеног и правичног третмана и радноправни прописи}

\section{1. Тумачење стандарда поштеног и правичног третмана}

Стандард поштеног и правичног третмана (енг. Fair and Equitable Treatment) је један од стандарда на чију се повреду страни улагачи најчешће позивају у арбитражном поступку. Обим и природа овог стандарда нису јасно одређени у међународном праву, већ зависе од тога како је у међународним уговорима о подстицању и заштити улагања овај стандард дефинисан. Тако, неки уговори прихватају идеју да је стандард поштеног и правичног третмана део међународног права, што води трибунале до закључка да он обухвата

4 Више о томе доступно на адреси: https://www.ilo.org/global/standards/introductionto-international-labour-standards/conventions-and-recommendations/langen/index. htm\#: :text=The\%20ILO\%20Governing\%20Body\%20has,forced\%20or\%20compulsory\%20 labour\%3B\%20the, 10. 1. 2021. 
међународни минимални стандард (енг. International Minimum Standard) како је прихваћен у међународном обичајном праву. ${ }^{5}$ Садржина међународног минималног стандарда се најчешће тумачи на начин како је трибунал описао у случају Neer, и то као „акт који представља тежак прекршај, непоштено поступање, намерно занемаривање дужности, недостатак деловања од стране државе које у тој мери није у складу са међународним стандардима да би свако разумно и непристрасно лице са лакоћом препознало недовољност оваквог поступања“6 С друге стране, када се међународни уговори не позивају на повезаност између стандарда поштеног и правичног третмана и међународног обичајног права, трибунали су тумачили садржину стандарда на основу његове формулације и дефиниције у међународним уговорима. Том приликом, арбитри су утврдили неколико елемената овог стандарда, као што је: да држава домаћин мора поступати на доследан начин, без нејасноћа и транспарентно; и да својим активностима не утиче на легитимна очекивања која је инвеститор узео у обзир приликом доношења своје одлуке о улагању. ${ }^{7}$

\section{2. Легитимна очекивања улагача и радноправни прописи}

\section{а) Тумачене леі̄итиммних очекивана улаїача}

Централна улога у оквиру стандарда поштеног и правичног третмана припада улагачевим легитимним очекивањима (енг. Legitimate Expectations) које улагачи формирају ослањајући се на правни оквир државе домаћина, као и на сва обећања и изјаве које је држава изричито или прећутно дала улагачу. ${ }^{8}$ Када је реч о правном оквиру, инвеститор се може ослонити на законодавство државе домаћина, као и на међународне уговоре које је држава закључила, затим обећања садржана у одлукама, дозволама и сличним извршним изјавама, као и обавезама преузетим у закљученим уговорима. ${ }^{9}$ Међутим, иако из реченог произлази да је стабилност правног оквира важна приликом доношења одлуке о улагању, легитимна очекивања улагача не могу утицати на

5 Вид. Северноамерички споразум о слободној трговини из 1994. године (North American Free Trade Agreement - NAFTA), чл. 1105.

6 Мишљење америчко-мексичке Комисије за опште захтеве (US-Mexico General Claims Commission), 15. октобар 1926. године, Neer v Mexico, пара. 4.

7 Tecmed v Mexico, ICSID Case No ARB (AF)/00/2, одлука од 29. 5. 2003, пара. 154.

8 Више о легитимним очекивањима улагача вид.: Петар Ђундић, „Легитимна очекивања као елемент стандарда поштеног и правичног третмана страних улагања у арбитражној пракси“, Зборних раgова Правної факулиетей у Новом Саgy, бр. 2/2014, 335-351.

9 Rudolf Dolzer, Christoph Schreuer, Principles of International Investment Law, 2nd edition, Oxford University Press, Oxford, 2012, 145. 
право државе да остварује своју суверену моћ, те да доноси законе и прилагођава свој правни систем новонасталим околностима. Ипак, мере које држава предузима не смеју превазилазити границе њене уобичајене регулаторне функције нити мењати преко прихватљиве границе регулаторни оквир који уређује улагања. ${ }^{10}$ Стога, легитимна очекивања улагача подразумевају предвидљивост и транспарентност правног оквира државе домаћина, али не и његову апсолутну непроменљивост. ${ }^{11}$ Због тога је за тумачење овог аспекта стандарда поштеног и правичног третмана неопходно применити тест балансирања, који подразумева да арбитражни трибунали морају вагати између легитимних и разумних очекивања улагача, с једне стране, и легитимних регулаторних интереса државе домаћина, с друге стране. ${ }^{12}$

Полазећи од аспекта радноправне заштите, инвеститорима би било тешко да докажу да нису могли основано да очекују да ће држава домаћин променити своје прописе о раду. Неки аутори су мишљења да би арбитражни трибунали приликом одлучивања увек требало да пођу од идеје да се јавно право мења, ${ }^{13}$ те да заговарају становиште да би улагачи, када улажу у земље у развоју, требало да узму у обзир специфичне економске и друштвене околности одређене државе. ${ }^{14}$ Овај став је потребно применити како у ситуацијама када држава доноси нова правна правила, тако и онда када предузима конкретне мере усмерене на улагача. ${ }^{15}$ Према томе, смернице за трибунал приликом тумачења стандарда поштеног и правичног третмана би биле да улагач не може претпоставити да ће домаћи прописи у области рада остати непромењени, али могу очекивати да ће држава домаћин спроводити своје политике у доброј вери, поступањем на начин који је разумно оправдан, те да такво понашање неће на очигледан начин кршити захтеве доследности, транспарентности, равномерности и недискриминације. ${ }^{16}$

С друге стране, било би легитимно и прихватљиво уколико би улагачи тражили заштиту од произвољних или дискриминаторних по-

10 R. Dolzer, C. Schreuer, 148. Вид.: Plama v Bulgaria, ICSID Case No. ARB/03/24, одлука од 27. 8. 2008, пара. 219; El Paso v Argentina, ICSID Case No. ARB/03/15, одлука од 31. 10. 2011, пара. 402.

11 Vivian Kube, Ernst-Ulrich Petersmann, „Human rights law in international investment arbitration", EUI Department of Law Research Paper, No. 2016/02, доступно на адреси: https://ssrn.com/abstract=2731770, 10. 1. 2021, 24.

12 Saluka v Czech Republic, делимична одлука, 17 3. 2006, UNICITRAL, пара. 306.

13 V. Kube, E. Petersmann, 25.

14 Вид. Ursula Kriebaum, „Are investment treaty standards flexible enough to meet the needs of developing countries?", Investment Law within International Law: Integrationist Perspectives (ed. Freya Baetens), Cambridge University Press, Cambridge, 2013, 330-340.

15 V. Kube, E. Petersmann, 25.

16 Saluka $v$ Czech Republic, пара. 307. 
ступака државе домаћина. ${ }^{17}$ Стога би арбитражни трибунал могао у одређеним ситуацијама да прихвати тврдњу да значајне и непредвидиве промене радноправног законодавства могу довести до повреде стандарда поштеног и правичног третмана. Ово посебно важи у ситуацијама када би такве промене значајно повредиле гаранције дате од стране државе у циљу привлачења страних улагања. ${ }^{18}$

Такође, неки аутори су приметили да се одговорни улагачи неће противити прогресивном побољшању заштите људских права, те поспешивању социјалних и еколошких стандарда државе домаћина, чак и уколико би таква реформа довела до додатних трошкова за саме улагаче. ${ }^{19}$ Стога, као један од предлога у циљу прецизирања појма легитимних очекивања инвеститора и рестриктивнијег тумачења стандарда поштеног и правичног третмана јесте уношење одредбе у међународне споразуме о заштити инвестиција којом би било предвиђено да „свака страна уговорница треба да подстакне привредна друштва која послују на територији њене државе, или су под њеном јурисдикцијом, да у оквиру свог пословања и унутрашње политике добровољно уграде међународно признате стандарде друштвено одговорног пословања, које су стране уговорнице одобриле или подржале, а који се односе на рад, животну средину, људска права, друштвене односе и борбу против корупције. “20 Тада би се могло аргументовати да овако „друштвено одговорни“ инвеститори не могу основано очекивати да држава домаћин неће испуњавати своје међународне обавезе наметнуте ратификованим конвенцијама Међународне организације рада, и то уносећи више стандарде радноправне заштите у домаће законодавство. ${ }^{21}$

17 Audley William Sheppard, Antony Crockett, „Are Stabilization Clauses a Threat to Sustainable Development?", Sustainable Development in World Investment Law (eds. MarieClaire Cordonier Segger, Markus W. Gehring, Andrew Newcombe), Kluwer Law International, the Netherlands, 2011, 348

18 Vid Prislan, Ruben Zandvliet, „Labor Provisions in International Investment Agreements: Prospects for Sustainable Development", Grotius Centre Working Paper, 2013/003-IEL, Leiden, 2013, доступно на адреси: https://papers.ssrn.com/sol3/papers.cfm?abstract_ $i d=2171716,10.1 .2021,46$.

19 A. W. Sheppard, A. Crockett, 348.

20 Вид.: Међународни уговор о заштити улагања између Републике Аргентине и Јапана, потписан 1. 12. 2018. године, није ступио на снагу, чл. 17; Међународни уговор о заштити улагања између Аустралије и Хонг Конга, потписан 1. 9. 2014. године, ступио на снагу 26. 3. 2019. године, чл. 16; Модел међународног уговора о заштити улагања Краљевине Холандије, 2019, чл. 7(2). Међународни уговори о заштити улагања су доступни на адреси: https://investmentpolicy.unctad.org/ international-investment-agreements, 6. 1.2021.

21 Katarina Maletić, Investor obligations under international law to respect labour rights and to comply with international labour standards, 2020, доступно на адреси: https://scripties.uba.uva.nl/search?id=c2971313, 11. 1. 2021, 16-17. 
Република Србија је унела описану одредбу о подстицању друштвено одговорног пословања компанија у свој Модел међународног споразума о унапређењу и заштити улагања, ${ }^{22}$ али је до сада закључила само два међународна споразума који садрже овакве одредбе, и то са Канадом (ступио на снагу 27. априла 2015. године) ${ }^{23}$ и са Републиком Турском (још увек није ступио на снагу), ${ }^{24}$ док је у Споразуму о слободној трговини између Европског удружења слободне трговине и Републике Србије у преамбули признат значај друштвено одговорног пословања и његовог доприноса одрживом развоју. ${ }^{25}$

\section{б) Сйабилизационе клаузуле и раянойравни ирройиси}

У области заштите радних права, стабилизационе клаузуле представљају најзначајнији пример обећања датих од стране држава домаћина инвеститорима у циљу подстицања улагања. Ове клаузуле имају за циљ да „замрзну“ правни поредак државе домаћина на одређени датум, тако да би усвајање било какве измене правног оквира који се односи на конкретно улагање био сматран незаконитим. ${ }^{26}$ Овај тип одредаба није садржан у међународним уговорима о унапређењу и заштити улагања, већ у уговорима које инвеститори закључују са државама домаћинима у циљу спровођења улагања. Ипак, неки арбитражни трибунали су прихватили да кишобран клаузуле (енг. Umbrella Clauses) у међународним споразумима о заштити инвестиција могу „подићи“ стабилизационе клаузуле на ниво заштите предвиђене овим међународним уговорима. ${ }^{27}$

Стабилизационе клаузуле су често предмет критика уз образложење да су противне промовисању одрживог развоја, а имајући у виду да омогућавају улагачима да се не придржавају закона усмерених ка остваривању циљева заштите људских права или животне средине. ${ }^{28}$ Као одговор на описани проблем, јавио се нови тренд у изради стаби-

22 Модел међународног уговора о заштити улагања Републике Србије, 2014, чл. 10.

23 Међународни уговор о заштити улагања између Републике Србије и Канаде, потписан 1. 9. 2014. године, ступио на снагу 27. 4. 2015. године, чл. 16.

24 Међународни уговор о заштити улагања између Републике Србије и Републике Турске, потписан 31. 1. 2018. године, није ступио на снагу, чл. 11.

25 Споразум о слободној трговини између Европског удружења слободне трговине и Републике Србије, потписан 17. 12. 2009. године, ступио на снагу 1. 10. 2010. године, преамбула.

26 Total S.A. v Argentina, ICSID Case No. ARB/04/1, одлука од 27. 12. 2010, пара. 101.

27 El Paso v Argentina, пара. 81.

28 Andrea Shemberg, „Investment Agreements and Human Rights: The Effects of Stabilization Clauses“, Working Paper No. 42, 2008, доступно на адреси: https://www.hks.har- 
лизационих клаузула који настоји да сузи њихово поље примене тако да обухвати само правне прописе из области пореског права или да им ограничи примену на одређени временски период. ${ }^{29}$

Стога, неки аутори су закључили да је неопходно направити разлику између пореских закона и еколошких и друштвених политика државе домаћина. Док за прве улагачи могу легитимно очекивати да ће држава гарантовати да се ови закони неће мењати, за друге улагачи не могу претпоставити да ће остати у целости непроменљиви. ${ }^{30} \mathrm{Ha}$ пример, уколико је држава домаћин дужна да усвоји одређене домаће прописе у циљу унапређења заштите права запослених, и то на основу одговарајуће ратификоване конвенције Међународне организације рада или као последица развоја међународног обичајног права, може се аргументовати да инвеститори не могу легитимно очекивати да држава домаћин неће мењати своје домаће радноправно законодавство. ${ }^{31}$

\section{3. Арбитражна пракса - случајеви Centerra $v$ Kyrgyz Republic, Veolia v Egypt и Paushokv Mongolia}

У овом одељку ће бити анализирана три случаја из арбитражне праксе у којима су улагачи покренули арбитражне поступке против држава домаћина као одговор на измене домаћег законодавства којима се регулишу различити аспекти услова рада. Прва два случаја која ће бити анализирана - Centerra $v$ Kyrgyz Republic и Veolia $v$ Egypt тичy ce повреде одредаба уговора закљученог између улагача и државе (а не повреде међународних уговора о подстицању и заштити улагања). У оба случаја, инвеститори су тврдили да су измене домаћег радноправног законодавства којима је подигнута минимална цена рада прекршиле стабилизационе клаузуле намењене управо заштити страних улагача од таквих измена правног оквира. Као што је претходно описано, стабилизационе клаузуле могу имати значајну улогу у тумачењу улагачевих легитимних очекивања. Стога, ови случајеви су значајни у откривању какве ставове су арбитражни трибунали заузимали о примени стандарда поштеног и правичног третмана у светлу измена прописа о раду. Ипак, релевантна документација из оба арбитражна предмета није јавно доступна, што отежава утврђивање ставова арбитара. Коначно, трећи

vard.edu/sites/default/files/centers/mrcbg/programs/cri/files/workingpaper_42_shemberg. pdf, 11. 1. 2021, пара. 146.

29 A. W. Sheppard, A. Crockett, 342.

30 Ibid., 347-348.

31 Више о односу између стабилизационих клаузула и стандарда правичног и поштеног третмана вид. Ruben Zandvliet, Trade, Investment and Labour: Interactions in International Law, doctoral thesis, Universiteit Leiden, Leiden, 2019, 156-163. 
случај који ће бити разматран - Paushok v Mongolia конципиран је на наводној повреди међународног споразума о заштити улагања.

Centerra v Kyrgyz Republic случај је покренут 2006. године, а централно место у спору је имала измена домаћих радноправних прописа којом је наметнута већа цена рада. Улагач је тврдио да је ова промена домаћег радног права повећала његове трошкове, те да је тиме прекршена стабилизациона клаузула предвиђена уговором закљученим између улагача и државе. ${ }^{32}$ Стране су се нагодиле 2009 . године, а сва релевантна документа из овог поступка су остала поверљива. ${ }^{33}$

У току 2012. године, француска компанија Veolia Proprete покренула је арбитражни поступак против Египта. Спор се делимично односио и на промене египатског радноправног законодавства, и то пре свега повећања минималних зарада. Инвеститор је тврдио да су ове измене правних прописа имале негативан утицај на компанију наносећи јој штету, иако је стабилизациона клаузула у уговору закљученом између државе и улагача требало управо да заштити улагаче од оваквих правних промена. ${ }^{34}$ 2018. године трибунал је наводно донео одлуку у корист Египта и одбио улагачев захтев за накнаду штете, али су пратећа документа, као и сама одлука остали недоступни јавности. ${ }^{35}$

Ипак, може се претпоставити да је један од средишњих елемената спора било тумачење инвеститорових легитимних очекивања. Ово пре свега подразумева дискусију око питања да ли улагачи могу основано очекивати да ће држава домаћин пристати на континуирану повреду радних права како би испоштовала стабилизационе клаузуле из уговора закљученим са улагачем, и то у ситуацијама када истовремено међународна заједница врши притисак на државу домаћина да подигне стандарде заштите права радника. ${ }^{36}$ Одлука донета у овом поступку

32 Вид. Centerra Gold, Centera Gold, Kumtor Mine Resumes Operations, 2006, доступно на адреси: https://s3.amazonaws.com/centerragold/news/July2018/GF2XnG0Jn5RXgUp8dY9t.pdf, 30. 12. 2020, интернет извор без броја стране.

33 Centerra Gold and Kumtor Gold v Kyrgyz Republic, повлачење захтева, PCA Case No. АА278, одлука од 29. 6. 2009, доступно на адреси: $h t t p s: / / p c a c a s e s . c o m / w e b / s e n d A t-$ tach/716, 30. 12. 2020.

34 Вид. Luke Eric Peterson, „French company, Veolia, launches claim against Egypt over terminated waste contract and labor wage stabilization promises", Investment Arbitration Reporter, 2012, доступно на адреси: https://www.iareporter.com/articles/french-company-veolia-launches-claim-against-egypt-over-terminated-waste-contract-and-labor-wagestabilization-promises/, 30. 12. 2020.

35 Вид. Damien Charlotin, „Egyptian official confirms victory in Veolia case at ICSID, as company remains silent", Investment Arbitration Reporter, 2018, доступно на адреси: https://www.iareporter.com/articles/egyptian-official-confirms-victory-in-veolia-case-aticsid-as-company-remains-silent/, 30. 12. 2020.

V. Kube, E. Petersmann, 13. 
може представљати значајан помак ка оснаживању права државе домаћина да унапреди услове рада у односу на улагачеве интересе. Ипак, конкретни аргументи и разлози за овакву одлуку остају тајна.

Случај Paushok v Mongolia покренут је у 2007. години, а једна од улагачевих тврдњи била је и наводна повреда стандарда поштеног и правичног третмана у контексту измена монголских прописа о раду. Наиме, Монголија је изменила услове за запошљавање страних радника од стране компанија које послују у области рударства, те је сходно новом законодавству компанија обавезана да плати накнаду једнаку десетоструком износу минималне месечне зараде за сваког страног радника којег запосли изнад $10 \%$ од укупног броја запослених. ${ }^{37}$ Из описаних разлога, улагач је тврдио да му је нови регулаторни оквир повећао трошкове рада, што је последично довело и до повреде стандарда поштеног и правичног третмана, с обзиром на то да је законодавна измена била арбитрарна, дискриминаторна и супротна његовим легитимним очекивањима. ${ }^{38}$ Трибунал је нашао да не постоје докази о томе да је законодавство државе домаћина, као и његова примена арбитрарна и неразумна. У прилог наведеном, указано је на то да је државама омогућено да уведу ограничења за запошљавање страних радника у различитим облицима и да та ограничења, укључујући притом и потпуну забрану запошљавања страних радника, не представљају аутоматски кршење међународног уговора о унапређењу и заштити улагања. Трибунал је такође појаснио да релевантни закони нису имали за циљ негативан утицај на конкретног улагача, већ да је рударски сектор стратешки значајан за Монголију, и стога је разумљиво да је држава имала намеру да наметне ограничења приликом запошљавања страних радника, како би се обезбедило запошљавање домаћих држављана. ${ }^{39}$

\section{III Индиректна експропријација и радноправни прописи}

\section{1. Појам индиректне експропријације}

У складу са идејом о суверенитету који држава остварује на својој територији, у међународном праву је прихваћено право државе домаћина да врши експропријацију имовине странаца. ${ }^{40}$ Међутим, да би се мо-

37 Вид. Sergei Paushok v Mongolia, одлука о надлежности и одговорности од 28. 4. 2011, пара. 108-110.

38 Ibid., пара. 353.

39 Ibid., пара. 364, 366 и 371.

40 R. Dolzer, C. Schreuer, 98. 
гао сматрати законитим, поступак експропријације мора да задовољи одређене услове који су потврђени у обичајном праву и уговорној пракси. Сходно томе, мера предузета од стране државе мора служити јавном интересу, не сме да буде произвољна и дискриминаторна, мора се спроводити у складу са законом и мора бити праћена плаћањем брзе, адекватне и ефикасне накнаде. ${ }^{41}$ Два основна облика експропријације су: директна (енг. Direct Expropriation), где се имовинска права улагача директно преносе, и индиректна (енг. Indirect Expropriation), када државна мера не укључује непосредно преношење имовинских права улагача, али која ефективно неутралише улагачево уживање у имовини. ${ }^{42}$

Имајући у виду да се државне мере усмерене ка заштити радних права могу потенцијално сматрати индиректном експропријацијом, неопходно је размотрити како су арбитражни трибунали у пракси тумачили овај облик експропријације. Стога ће у наставку бити анализирано да ли улагачи могу тврдити да ново радноправно законодавство и његова примена лишавају улагача употребе и уживања његове имовине, те му омогућавају да потражује адекватну компензацију од државе.

\section{2. Тумачење индиректне експропријације}

Арбитражни трибунали се разликују у приступима које су прихватили како би утврдили да ли конкретна државна мера испуњава услове да се може сматрати индиректном експропријацијом. У арбитражној пракси су се појавиле две главне линије аргумената: прва се назива доктрином ефеката (енг. Sole Effects Doctrine), а друга доктрином полицијске моћи (енг. Police Power Doctrine). ${ }^{43}$ у зависности од тога који од наведена два приступа арбитри прихвате, иста државна мера може бити различито тумачена.

Најпре, према доктрини ефеката, основни фактор да ли је дошло до индиректне експропријације представља ефекат државне мере на конкретно улагање, као и на правни положај улагача. Државни интерес, као и циљ и сврха мере, нису релевантни. Овај приступ је, на пример, прихваћен у случају Metalcad v Mexico, где је трибунал закључио да не треба утврђивати мотив или намеру државе приликом усвајања конкретне мере, ${ }^{44}$ већ искључиво њене ефекте. Стога, ако је државна мера довела до значајног задирања у имовинска права улагача, чињеница да

\footnotetext{
41 Ibid., 99-100.

42 CMS v Argentina, ICSID Case No. ARB/01/8, одлука од 12. 5. 2005, пара. 262.

43 Rudolf Dolzer, Felix Bloch, „Indirect Expropriation: Conceptual Realignments“, International Law FORUM Du Droit International, Nr. 3/2003, 158.

44 Metalclad v Mexico, ICSID Case No. ARB(AF)/97/1, одлука од 30. 8. 2000, пара. 111.
} 
она истовремено регулише услове рада и заштите радних права неће лишити ову меру њеног експропријацијског карактера. ${ }^{45}$

Ипак, полазећи од природе радноправног законодавства и ефекта који његове измене могу остварити на улагачева имовинска права, мало је вероватно да га улагачи могу оспоравати тврдећи да би његова измена представљала незакониту експропријацију. Наиме, радноправни прописи се разликују од државних мера у доменима заштите животне средине и јавног здравља. У овим областима, држава може повлачити или опозивати дозволе дате инвеститорима у циљу заштите животне средине или забранити употребу одређених хемикалија за које се сматра да представљају претњу по јавно здравље. ${ }^{46}$ Овакве мере, на основу којих улагачи могу тврдити да су им одузета имовинска права, ретко се могу појавити у области радних права.

Друга линија аргумента, која је прихваћена под називом доктрина полицијске моћи, не базира анализу државне мере само на одређивање њених ефеката, већ узима у обзир и државне интересе везане за конкретну меру, те тиме наводи трибунале на сложеније процесе вагања и балансирања у циљу доношења одлуке. ${ }^{47}$ Тако, неки трибунали су потврдили да полицијска моћ државе (енг. Police Power) представља принцип међународног обичајног права и прихватили да државе домаћини имају могућност да ограниче имовинска права улагача без плаћања накнаде. ${ }^{48}$ Ипак, речено важи само под условом да државна мера поседује легитимну сврху и уколико постоји одговарајућа равнотежа у односу на ефекат који мера остварује на инвестицију. ${ }^{49}$ Овај приступ наглашава да држава има право да усвоји мере које имају „социјалну или општу сврху“, 50 али да и тада мора постојати пропорционалан однос између тежине утицаја на улагача и његова права и циља који се жели постићи овом мером. ${ }^{51}$

45 Вид. Ursula Kriebaum, „Human Rights of the Population of the Host State in International Investment Arbitration“, Journal of World Investment \& Trade, Nr. 5/2009, 653677.

46 R. Zandvliet, 152.

47 R. Dolzer, F. Bloch, 158.

48 Phillip Morris v Uruguay, ICSID Case No. ARB/10/7, одлука од 8. 7. 2016, пара. 294297.

49 Вид. Benedict Kingsbury, Stephan Schill, „Public law concepts to balance investors' rights with state regulatory actions in the public interest - the concept of proportionality", International Investment Law and Comparative Law (ed. Stephan Schill), Oxford University Press, Oxford, 2010.

50 LG\&E Energy Corp. v Argentina, ICSID Case No. ARB/02/1, одлука од 3. 10. 2006, пара. 195.

51 Tecmed v Mexico, пара. 122. 
Према томе, полазећи од овог приступа, а у циљу утврђивања да ли је дошло до незаконите експропријације, трибунали би морали да истраже да ли је државна мера недискриминаторска и пропорционална, као и да ли се предузима добронамерно у сврху заштите јавног благостања. ${ }^{52}$ Стога, чак и уколико би карактер измене радноправног законодавства био такав да инвеститоре лишава њихових имовинских права, мало је вероватно да би улагачи доказали у арбитражном поступку да је дошло до незаконите експропријације. Наиме, може се аргументовати да прописи усмерени ка заштити радних права и услова рада имају легитимну сврху и да су садржани у јавним интересима државе, док би трибунали утврђивали на основу чињеница конкретног случаја да ли су испуњени услови пропорционалности и недискриминаторности државне мере.

\section{3. Арбитражна пракса - случај Foresti $v$ South Africa}

У арбитражној пракси није било случајева у којима је инвеститор успешно оспорио измене радноправног законодавства државе домаћина позивајући се на индиректну експропријацију. Ипак, случај Foresti $v$ South Africa представља важан пример у овом контексту, с обзиром на то да је циљ оспорених мера било укидање недискриминације у запошљавању и занимању - мере које су инвеститори оспоравали у арбитражном поступку позивајући се на незакониту индиректну дискриминацију.

У средишту спора биле су политике економског оснаживања положаја црнаца у Јужној Африци (енг. South Africa’s Black Economic Empowerment), које су настојале да смање расну неједнакост укорењену у наслеђе апартхејда, те да појачају учешће црнаца у рударском сектору. ${ }^{53}$ Улагачева оспоравања су, између осталог, била усмерена против обавеза које им је наметало ново законодавство, а које је подразумевало и обавезу радног ангажовања категорије „историјски угрожених Јужноафриканаца“ (енг. Historically Disadvantaged South Africans). ${ }^{54}$ Наиме, као један од главних циљева рударске индустрије било је постизање једнакости у запошљавању, и то тако што ће се у периоду од пет година остварити учешће од 40\% категорије „историјски угрожених Јужноафриканаца“ у управљању рударском индустријом, као и учешће од $10 \%$ жена у овом

52 Phillip Morris v Uruguay, пара. 305.

53 Damon Vis-Dunbar, South African court judgment bolsters expropriation charge over Black Economic Empowerment legislation in the mining sector, 2009, доступно на адреси: https://cf.iisd.net/itn/2009/03/23/south-african-court-judgment-bolsters-expropriation-charge-over-black-economic-empowerment-legislation/, 6. 1. 2021, интернет извор без броја стране.

54 V. Prislan, R. Zandvliet, 43. 
сектору. ${ }^{55}$ Трибунал никада није одлучивао о меритуму спора, с обзиром на то да су стране постигле споразум, а поступак је обустављен. ${ }^{56}$ Стога, арбитри нису имали могућност да изложе своје тумачење индиректне експропријације у односу на мере из области радног права.

\section{IV Закључак}

Измене домаће регулативе државе домаћина у области рада тешко могу имати карактер индиректне експропријације, с обзиром на то да измене радноправних прописа углавном не задиру озбиљније у улагачева имовинска права. Ово потврђује и изостанак релевантне арбитражне праксе у којој су инвеститори успешно оспорили домаће прописе о раду позивајући се на незакониту експропријацију.

Када је реч о стандарду поштеног и правичног третмана, његов основни циљ је да заштити улагаче од произвољних или дискриминаторних државних мера. Стога, полазећи од аспекта радноправне заштите, не може се закључити да би овај стандард заштитио улагаче од увођења bona fide радноправних прописа, а инвеститори би са тешкоћом могли доказати да нису могли основано очекивати да ће држава домаћин променити своје прописе о раду. Ово нарочито важи када је реч о улагању у земље у развоју, попут Републике Србије, које настоје да ускладе свој правни поредак са међународним принципима заштите радних права. Изузетно, уколико би улагач доказао да су непредвидиве промене радноправног законодавства значајно повредиле гаранције дате од стране државе у циљу привлачења страних улагања, арбитражни трибунали би могли наћи да је дошло до повреде стандарда поштеног и правичног третмана.

Коначно, у циљу рестриктивнијег тумачења легитимних очекивања улагача, међународни споразуми о заштити улагања би требало да садрже одредбе о подстицању друштвено одговорног пословања компанија. Наиме, овако „друштвено одговорни“ инвеститори би са тешкоћом могли тврдити да је за њих било неочекивано да држава домаћин неће у свој правни поредак настојати да инкорпорише међународне стандарде заштите радних права. Стога је препоручљиво да Република Србија и у пракси следи свој Модел међународног споразума о заштити инвестиција, те да у међународним уговорима које закључује уно-

55 Scorecard for the Broad-Based Socio-Economic Empowerment Charter for the South African Mining Industry, Notice 1639, 2004, доступно на адреси: https://www.mqa.org. za/sites/default/files/Mining\%20Charter\%20August\%202004.pdf, 6. 1. 2021, одељак 4.2.

56 Piero Foresti $v$ South Africa, ICSID Case No. ARB(AF)/07/0, одлука од 4. 8. 2010, пара. 79-82. 
си одредбе које се баве питањима друштвене одговорности улагача. У том смислу је приметан позитиван тренд, имајући у виду да последњи међународни споразуми које је Република Србија закључила (са Канадом и Републиком Турском) садрже описане одредбе.

\section{Коришћена литература}

Brower Charles, Blanchard Sadie, „What's in a Meme? The Truth about Investor-State Arbitration: Why It Need Not, and Must Not, be Repossessed by States", Columbia Journal of Transnational Law, Vol. 52, Nr. 3/2014.

Vis-Dunbar Damon, South African court judgment bolsters expropriation charge over Black Economic Empowerment legislation in the mining sector, 2009, доступно на адреси: https://cf.iisd.net/itn/2009/03/23/ south-african-court-judgment-bolsters-expropriation-charge-over-blackeconomic-empowerment-legislation/, 6. 1. 2021.

Dolzer Rudolf, Bloch Felix, „Indirect Expropriation: Conceptual Realignments“, International Law FORUM Du Droit International, Nr. 3/2003.

Dolzer Rudolf, Schreuer Christoph, Principles of International Investment Law, 2nd edition, Oxford University Press, Oxford, 2012.

Ђундић Петар, „Легитимна очекивања као елемент стандарда поштеног и правичног третмана страних улагања у арбитражној пракси“, Зборних раяова Правноі фбаклитети а у Новом Саgу, бр. 2/2014. (Đundić Petar, „Legitimna očekivanja kao element standarda poštenog i pravičnog tretmana stranih ulaganja u arbitražnoj praksi“, Zbornik radova Pravnog fakulteta u Novom Sadu, br. 2/2014).

Eric Peterson Luke, „French company, Veolia, launches claim against Egypt over terminated waste contract and labor wage stabilization promises“, Investment Arbitration Reporter, 2012, доступно на адреси: https://www.iareporter.com/articles/french-company-veolia-launchesclaim-against-egypt-over-terminated-waste-contract-and-labor-wagestabilization-promises/, 30. 12. 2020.

Zandvliet Ruben, Trade, Investment and Labour: Interactions in International Law, doctoral thesis, Universiteit Leiden, Leiden, 2019.

Kingsbury Benedict, Schill Stephan, „Public law concepts to balance investors’ rights with state regulatory actions in the public interest - the concept of proportionality", International Investment Law and Comparative Law (ed. Stephan Schill), Oxford University Press, Oxford, 2010.

Kriebaum Ursula, „Human Rights of the Population of the Host State in International Investment Arbitration“, Journal of World Investment \& Trade, Nr. 5/2009. 
Kriebaum Ursula, „Are investment treaty standards flexible enough to meet the needs of developing countries?", Investment Law within International Law: Integrationist Perspectives (ed. Freya Baetens), Cambridge University Press, Cambridge, 2013.

Kube Vivian, Petersmann Ernst-Ulrich, „Human rights law in international investment arbitration“, EUI Department of Law Research Paper, No. 2016/02, доступно на адреси: https://ssrn.com/abstract=2731770, 10. 1. 2021.

Maletić Katarina, Investor obligations under international law to respect labour rights and to comply with international labour standards, 2020, доступно на адреси: https://scripties.uba.uva.nl/search?id=c2971313, 11.1. 2021.

Prislan Vid, Zandvliet Ruben, „Labor Provisions in International Investment Agreements: Prospects for Sustainable Development", Grotius Centre Working Paper, 2013/003-IEL, Leiden, 2013, доступно на адреси: https://papers.ssrn.com/sol3/papers.cfm?abstract_id=2171716, 10.1. 2021.

Shemberg Andrea, „Investment Agreements and Human Rights: The Effects of Stabilization Clauses“, Working Paper No. 42, 2008, доступно на адреси: https://www.hks.harvard.edu/sites/default/files/centers/mrcbg/ programs/cri/files/workingpaper_42_shemberg.pdf, 11. 1. 2021.

Sheppard Audley William, Crockett Antony, "Are Stabilization Clauses a Threat to Sustainable Development?", Sustainable Development in World Investment Law (eds. Marie-Claire Cordonier Segger, Markus W. Gehring, Andrew Newcombe), Kluwer Law International, the Netherlands, 2011.

Charlotin Damien, „Egyptian official confirms victory in Veolia case at ICSID, as company remains silent", Investment Arbitration Reporter, 2018, доступно на адреси: https://www.iareporter.com/articles/egyptianofficial-confirms-victory-in-veolia-case-at-icsid-as-company-remainssilent/, 30. 12. 2020.

Choudhury Barnali, „Investor Obligations for Human Rights“, ICSID Review (Forthcoming), 2019, доступно на адреси: https://ssrn.com/abstract $=3500991,10.1 .2021$. 
Katarina MALETIĆ, LL.M.

Judicial Assistant at the Higher Court in Belgrade, Republic of Serbia

\title{
INTERNATIONAL INVESTMENT LAW AND LABOUR RIGHTS PROTECTION: A STANDARD OF FAIR AND EQUITABLE TREATMENT AND INDIRECT EXPROPRIATION IN THE LIGHT OF CHANGES IN HOST COUNTRY LABOUR LAW
}

\begin{abstract}
Summary
The purpose of this paper is to answer the question whether investors may challenge domestic labour legislation by invoking breach of international investment agreements, in particular violations of fair and equitable treatment standard, as well as illegal expropriation of investments. The answer to this question is especially relevant for developing countries, such as the Republic of Serbia, which seek to harmonize their legal systems with international principles of labour rights protection. Therefore, the paper will explore the interpretations of the fair and equitable treatment standard and indirect expropriation given by arbitration tribunals and accepted among scholars, as well as their application with respect to the labour regulation changes. Particularly analysed is the relevant case law before arbitration tribunals dealing with the question whether host states may violate these standards by amending their domestic labour legislation. Research has shown that domestic labour regulation amendments may rarely be interpreted as indirect expropriation, while the fair and equitable treatment standard may be breached in case of unpredictable labour legislation changes which would significantly violate guarantees given by the state to attract foreign investments but cannot protect investors from the introduction of bona fide labour regulations.
\end{abstract}

Key words: $\quad$ Labour Regulations. - Fair and Equitable Treatment Standard. - Legitimate Expectations. - Stabilization Clauses. - Indirect Expropriation. 